\title{
Epistemiczne podstawy badań metodami mieszanymi
}

\author{
DOI: http://dx.doi.org/10.12775/ZN.2019.011
}

Interdyscyplinarność badań naukowych jest zjawiskiem złożonym i wielopoziomowym (Niiniluoto 2020). Dlatego w niniejszej wypowiedzi odniosę się do tego rodzaju badań interdyscyplinarnych, których przejawem jest wykorzystywanie różnych metod badawczych, często wiązanych z przeciwstawnymi paradygmatami, jak postpozytywistyczny oraz interpretatywistyczny (Kawalec 2014). Kwestia, którą tu podejmuję, dotyczy epistemicznej zasadności takich badań, rozumianej ogólnie jako związanej z osiąganiem zasadniczego celu badań, jakim jest prawdziwość wniosków, do których one prowadzą (truth goal). Jest to rzadko poruszane zagadnienie w odniesieniu do badań interdyscyplinarnych, co niekiedy tłumaczy się ich praktycznym ukierunkowaniem. Wiążą się one zasadniczo $\mathrm{z}$ dostrzeganiem kompleksowych problemów badawczych, których rozstrzygnięcie ma istotne konsekwencje dla dużych grup ludzkich (Mäki 2016). Z kolei tradycyjne pytania epistemologiczne ukierunkowane są na ogół przez tradycję dociekań filozoficznych, które podążają tropem rozwoju poszczególnych dyscyplin naukowych, zwłaszcza najbardziej dojrzałych metodologicznie (np. geometria, astronomia, fizyka, biologia). Pozostaje więc pytanie, czy w badaniach, wykorzystujących różne metody naukowe, możliwe jest osiągnięcie spójnej epistemicznie odpowiedzi, odzwierciedlającej kompleksowość podjętego problemu, czy raczej tego typu badania interdyscyplinarne nieuchronnie prowadzą do konglomeratu luźno powiązanych rozstrzygnięć, które mają znaczenie w obrębie tradycyjnie wyróżnionych poszczególnych dyscyplin.

Jedną z możliwych prób odpowiedzi na pytanie o zasadność epistemiczną znajdujemy w Logicznych podstawach prawdopodobieństwa Rudolfa Carnapa (2021). Wprowadzone zostało tam pojęcie dowodu całkowitego (total evidence), które miało przede wszystkim służyć rozwiązaniu notorycznych problemów wnioskowań indukcyjnych (zwłaszcza tzw. sylogizmu statystycznego). Bez odniesienia w przesłankach do dowodu całkowitego poszczególne wnioskowania, bazując na różnych (fragmentarycznych) przesłankach, mimo zastosowania tych samych 
reguł wnioskowania, mogą prowadzić do wniosków, które są ze sobą niezgodne lub wręcz sprzeczne. Postulat wykorzystania dowodu całkowitego w ujęciu Carnapa sprowadza się do każdorazowego posługiwania się koniunkcją wszystkich zdań, składających się na znany materiał empiryczny (evidence). Dzięki temu wnioskowania indukcyjne, które przebiegają według tych samych reguł, nie mogą już prowadzić do rozbieżnych wniosków.

Oczywistą wadą takiej propozycji jest jednak jej zbyt wyidealizowany charakter. Po kilku dekadach dyskusji, ukształtowanej m.in. pod wpływem Jerry'ego Fodora, zaproponowano szereg argumentów, które istotnie podają w wątpliwość przyjmowany przez Carnapa fizykalizm, a więc redukcję wszystkich dyscyplin naukowych do jednego wspólnego rdzenia, jakim miałaby być fizyka. Ponadto naukowcy w procesie badawczym ograniczają się wyłącznie do istotnych przesłanek, gdyż przywoływanie wszystkich znanych ustaleń empirycznych sprawiałoby, że wyprowadzenie nawet najprostszego wniosku byłoby zadaniem niewykonalnym. Mimo tych oczywistych trudności postulat Carnapa pozostaje wciąż aktualną i przyciągającą uwagę propozycją epistemologiczną. Podobnie będzie także w tej wypowiedzi, ale zaproponuję pewne jego zawężenie.

Przedtem chciałbym w odniesieniu do badań interdyscyplinarnych, wykorzystujących różne metody badawcze, wprowadzić pewne istotne dla niniejszych rozważań odróżnienie. Otóż tego rodzaju badania zwykle są inicjowane na jeden z dwóch sposobów. Społeczeństwa demokratyczne, poprzez swoich reprezentantów, określają podstawowe preferencje (Kitcher 2001), które następnie wyznaczają poszczególne polityki publiczne, służące ich zaspokojeniu. Takie polityki obejmują zdrowie publiczne, obronność, rozwój gospodarczy, ochronę środowiska itp. W ramach realizacji polityk publicznych wyznaczane są obszary wymagające wygenerowania wiedzy naukowej, która ma służyć dostarczeniu nowych rozwiązań dla palących problemów społecznych, a w szczególności tzw. wielkich wyzwań (grand challenges). Wiele z tych problemów ma charakter kompleksowy, w związku z czym decydenci stosują różnego typu bodźce do rozwijania badań podejmujących kompleksowe zagadnienia, wykraczające poza tradycyjne ramy poszczególnych dyscyplin. Ten model rozwijania badań interdyscyplinarnych został scharakteryzowany w literaturze naukoznawczej jako Mode-2. W dalszej części tej wypowiedzi będę odnosił się do niego jako instytucjonalnego (odgórnego) modelu badań interdyscyplinarnych (Woleński 2016).

Obok niego jednak istnieje inny model. Bazuje on na wyrastającej z badań naukowych świadomości niedoskonałości dotychczasowych rozstrzygnięć i ciągłego poszukiwania bardziej zadowalających odpowiedzi na wyjściowe pytania badawcze. Często jednak, w przeciwieństwie do Mode-2, proces kształtowania się takiej świadomości jest długotrwały, skokowy i wiąże się z okresami przejściowymi, które umożliwiają podjęcie nowej refleksji, zaproponowanie nowej perspektywy czy wykorzystanie nowych narzędzi badawczych (Kawalec 2018). Ten 
model rozwijania badań interdyscyplinarnych w dalszej części będę określał jako problemowy (oddolny). W tym przypadku badania interdyscyplinarne są emergentnym efektem tradycyjnych badań. Jednak w przeciwieństwie do Mode-2 instytucjonalne formy realizacji takich badań pojawiają się w tej sytuacji jako efekt uboczny realizacji procesów badawczych. Ponadto dotyczą one badań podstawowych, podczas gdy badania w trybie Mode-2 mają na celu zastosowanie dotychczasowej wiedzy do rozwiązania problemu społecznego. To przeciwstawienie dwóch modeli badań interdyscyplinarnych, instytucjonalnego i problemowego, odzwierciedla znane w metodologii ekonomii odróżnienie pojęcia racjonalności konstruktywistycznej i racjonalności ekologicznej. I podobnie jak tam, również w odniesieniu do badań interdyscyplinarnych oba modele odgrywają istotne role i wzajemnie się uzupełniają.

Powróćmy teraz do Carnapa pojęcia dowodu całkowitego. W sposób charakterystyczny dla poglądów empiryzmu logicznego badacz ten starał się określać to pojęcie w kategoriach semantycznych, przede wszystkim odnosząc się do uznanych za prawdziwe zdań będących raportami z bezpośrednich obserwacji. Pewnych, wskazanych wcześniej trudności pierwotnego pojmowania dowodu całkowitego można uniknąć przez odniesienie pragmatyczne (w sensie Charlesa Morrisa) tego pojęcia do procesu badawczego, w ramach którego wykorzystywany jest dowód całkowity. Z elementów procesu badawczego najbardziej istotne są w tym przypadku otwarte pytania, będące efektem wcześniejszych procesów badawczych, na które do tej pory nie znaleziono odpowiedzi, instrumentarium metod, które dotychczas wykorzystywano w badaniach, a także teoretyczna konceptualizacja problemów za pomocą modeli, praw lub teorii naukowych. Takie pragmatyczne ujęcie stanu wiedzy oraz niewiedzy w odniesieniu do badanego zagadnienia zawęża pojęcie dowodu całkowitego, zarówno do wspólnoty badaczy zainteresowanych daną problematyką („niewidzialny koledż”), jak i aktualnego stanu ich wiedzy o niej. Dla interdyscyplinarności oddolnej istotne jest zaprojektowanie planu badań w nowym procesie badawczym w taki sposób, który dzięki włączeniu do instrumentarium nowych metod pozwoli w jednym procesie badawczym na uzyskanie odpowiedzi na pytanie, które pozostawało otwarte. W przypadku, gdy włączone do procesu badawczego metody mają wystarczająco różny charakter (zwłaszcza ilościowe vs. jakościowe), mamy do czynienia z badaniem metodami mieszanymi.

Przeciwieństwem zastosowania scharakteryzowanego tu ograniczonego postulatu dowodu całkowitego jest takie planowanie badań, żeby do takiego planu włączone zostały tylko te pytania, na które można odpowiedzieć, stosując wyłącznie znane, rutynowe metody badań. Oznacza to odsunięcie z pola zainteresowań pewnych otwartych pytań, które wykraczają poza aktualnie dostępne instrumentarium badawcze. Jednym $\mathrm{z}$ najbardziej długotrwałych przykładów tego typu prowadzenia badań jest tzw. cholera laboratoryjna (Kawalec 2018), związana $\mathrm{z}$ ograniczeniem na kilkadziesiąt lat pola zainteresowań w badaniach nad 
cholerą przez sposób prowadzenia badań opracowany przez Roberta Kocha. To swoistego rodzaju ,zamrożenie" sposobu prowadzenia badań silnie utrwalało te wzorce dyscyplinowe, głównie za sprawą kontynuatorów Kocha, który pozostawił po sobie liczną grupę wychowanków. Dopiero wyjście poza ten schematyczny sposób badania przecinkowca cholery pozwoliło na odkrycie od dawna postulowanej „trucizny” cholery (zwłaszcza egzotoksyn), co z kolei umożliwiło opracowanie mechanizmu powstawania choroby po prawie 80 latach od pierwszych badań Kocha nad tą bakterią.

Emergentne kształtowanie się interdyscyplinarności problemowej jest w oczywisty sposób uwarunkowane samą specyfiką przedmiotu badania. Można więc oczekiwać istotnego zróżnicowania intensywności takiej interdyscyplinarności w odniesieniu do przedmiotów badań o różnym stopniu złożoności (Pigliucci 2019). Stosunkowo najmniej podatne na tę interdyscyplinarność będą przede wszystkim przedmioty o najmniejszej złożoności, jaką charakteryzują się m.in. obiekty badań przyrodniczych, np. w fizyce cząstek, fizyce jądrowej czy astrofizyce. $Z$ kolei największą złożonością będą odznaczać się przedmioty badane w naukach społecznych czy humanistycznych, np. w zakresie epidemiologii czy zdrowia publicznego.

Postulowany przez Carnapa dowód całkowity był zamierzony jako narzędzie dla wszystkich dyscyplin naukowych posługujących się wnioskowaniami indukcyjnymi. W zaproponowanej tu ograniczonej postaci dostarcza on podstaw epistemicznych badaniom interdyscyplinarnym, a w szczególności działaniom prowadzonym metodami mieszanymi, gdyż wspomaga realizację zasadniczego celu badań naukowych, jakim jest osiąganie prawdziwości (truth goal). Stosowanie tego postulatu wyprowadza badania naukowe poza fenomen rozwiązywania zagadek (puzzle solving), o którym pisał Thomas Kuhn, ukierunkowując je na autentyczne rozwiązywanie problemów i uzyskiwanie kompleksowych odpowiedzi. Interdyscyplinarność odgórna również może prowadzić do wykorzystania w badaniu zróżnicowanych metod badawczych. Jednak będzie to przypadek procesu badawczego z wykorzystaniem wielu metod (multi method), z których każda może powielać schemat rozwiązywania zagadek z różnych obszarów, do uzyskania cząstkowych odpowiedzi na odmienne pytanie badawcze, co w efekcie może stanowić mozaikę różnych odpowiedzi, powiązanych ze sobą w niewielkim stopniu, w szczególności niewskazujących powiązań w postaci mechanizmów przyczynowych. 


\section{Bibliografia}

Carnap R., 2021, Logiczne podstawy prawdopodobieństwa, tłum. i wstęp P. Kawalec, Warszawa: Wydawnictwo Naukowe PWN, w opracowaniu.

Kawalec P., 2014, „Metody mieszane w kontekście procesu badawczego w naukoznawstwie”, Zagadnienia Naukoznawstwa 50(1): 3-22.

Kawalec P., 2018, Metodologia integralna: studium dynamiki wiedzy naukowej, Lublin: Wydawnictwo KUL.

Kitcher P., 2001, Science, truth, and democracy, Oxford: Oxford University Press.

Mäki U., 2016, "Philosophy of interdisciplinarity. What? Why? How?", European Journal for Philosophy of Science 6(3): 327-342.

Niiniluoto I., 2020, "Interdisciplinarity from the perspective of critical scientific realism", [w:] Gonzalez W. J. (ed.), New approaches to scientific realism, Berlin: De Gruyter, 231-250.

Pigliucci M., 2019, Bujda na resorach. Jak odróżnić naukę od bredni, tłum. P. Kawalec, Warszawa: Wydawnictwo Naukowe PWN.

Woleński J., 2016, „O wewnętrznej i zewnętrznej integracji nauk”, Zagadnienia Naukoznawstwa 52(1): 5-14. 
